\title{
Developing third-party purchase (3PP) services: New Zealand third-party logistics providers' perspectives
}

\author{
Yangyan Shi ${ }^{\mathrm{a}, \mathrm{b}}$, Tiru Arthanari ${ }^{\mathrm{c}}$, Lincoln C. Wood ${ }^{\mathrm{d}, \mathrm{e}}$
}

a. School of Economics and Management, Shanxi University, Shanxi, China, 213164

Tel: (86)519 86330550; Email: yshi@cczu.edu.cn

b. Centre for Supply Chain Management, University of Auckland Business School, Auckland, New Zealand

c. Department of Information Systems and Operations Management, University of Auckland Business School, Auckland, New Zealand

Tel: (64) 9923 4857; E-mail: t.arthanari@auckland.ac.nz

d. Graduate School of Management, University of Auckland Business School, Auckland, New Zealand Tel: (64) 9923 5820; E-mail: L.Wood@auckland.ac.nz

e. School of Information Systems, Curtin University, Bentley, Australia

\section{Abstract \\ Purpose}

This research examines the opportunity for third-party logistics providers (3PLs) to develop further value-added services for their clients, focused on purchasing. The provider perspectives on third-party purchase (3PP) services are examined in conjunction with their business environment, with a survey informed by transaction cost economics (TCE).

\section{Design/methodology/approach}

New Zealand 3PL providers were surveyed and 166 responses were received. Structural equation modeling was employed to test the conceptual model.

\section{Findings}

From the perspective of 3PL providers, uncertainty, frequency, and transaction size, but not asset specificity, are significantly associated with client value from a 3PP service. While asset specificity in investments is not required by 3PLs, they need a high frequency of orders, sufficient order size, and low levels of uncertainty as supporting conditions for the development of 3PP services.

\section{Originality / value}

This study shows that 3PP services may be further developed by 3PL providers to improve the value offered to their clients.

\section{Research limitations}

The sample focuses on 3PL providers and therefore does not address the behavioral characteristics of users or customers of the services.

Keywords: Third-party logistics; Third-party purchase; Transaction cost analysis; Structural equation modeling; Supply chain management; New Zealand

Paper type: Research paper 


\section{Introduction}

While there has been sustained growth in the 3PL market over the past decade, much of this growth has been within the traditional 3PL services of warehousing and domestic transportation (Langley, 2016). As a consequence, many 3PL firms have been seeking alternative pathways forward as they transition to a service model where they increasingly add more value for their customers (Manzini et al., 2006; Rushton et al., 2006). While developing further value-added services, the scope of their activities will often expand from their traditional transport and warehousing based functions to encompass other elements of the value chain by providing differentiated services (Hong \& Liu, 2007). One method which is increasingly gaining attention and recognition as a value-added service for customers is the inclusion of procurement activities on behalf of their key customers (Shi \& Arthanari, 2011) - this is known as third-party purchasing (3PP).

The opportunity to develop further services is important for 3PLs given their role in facilitating international trade. As a bridge conduit for international trade, 3PLs have gradually shifted their service offerings by including more working customers brokering trade support functions. In this way, they have more closely integrated and formed closer bonds with key customers. Because 3PLs have become more tightly integrated within global supply chains, they have also been exposed to increased volatility along vertical supply chains (Yang \& Zhao, 2016). The integration encourages 3PLs to enhance the benefits to clients regarding profit, inventory control, and flexibility (Power et al., 2007). One emerging service that has been proposed to reduce difficulties for clients and increase value-added services for them has been the aggregation of the management of many of the procurement functions over the supply chain - the concept of 3PP (Shi \& Arthanari, 2011). The concept of 3PP broadly means that the customer firm outsources the purchasing function to the 3PL, who then have the role of a group purchasing agent. Group purchasing, therefore, is a form of horizontal cooperation that aids customer firms and their focus on core activities while reducing the costs of the non-core activities (Cruijssen et al., 2007). Also, volume aggregation achieved with a single purchaser enables stronger negotiation that can result in deriving a better value proposition for clients (Schotanus \& Telgen, 2007). Therefore, the concept of a 3PP service has many attractive attributes and features, and it fits well within the scope of the 3PL shift towards more diverse valueadded services, despite the focus by many 3PLs on traditional logistics activities.

There is a range of activities that may be outsourced to 3PLs and this suggests there are further opportunities to develop services for clients. Outsourcing has been recognized as a method to reduce costs and allow firms to focus on core activities and the scope of outsourced activities. While 
outsourcing with the intention to only reduce costs has been seen as short-sighted and unadvisable (Kakabadse \& Kakabadse, 2002), outsourcing of engineering commodity item procurement can still have significant financial savings (Parry et al., 2006). There has been an increasing trend towards further investigation of purchasing and supply management based on rigorous research (Spina et al., 2013). Despite the growing interest, it is not always clear how 3PL providers perceive and use the opportunity to develop new value-added services and then use these to differentiate their client offerings in the marketplace.

This paper, therefore, addresses the research question of how 3PL providers perceive the opportunities presented by developing and offering 3PP services, with a particular focus (informed by transaction cost economics) on the role of asset specificity and uncertainty. This research is important as while growth is strong and many firms have not fully exploited outsourcing (Minonne \& Turner, 2012; Palugod \& Palugod, 2011), little is known about how 3PLs perceive the opportunities afforded by the development of these types of value-added services. While there are existing theoretical frameworks that highlight these opportunities (Shi \& Arthanari, 2011), there is little empirical evidence that would support service providers' efforts to develop these value-added services. Existing research has focused on the 3PL providers in the emerging market of China (Shi et al., 2016a); however, there are important and significant logistics infrastructural differences between markets that can influence performance (Jiang, Frazier, \& Heiser, 2007; Nguyen \& Tongzon, 2010) and so further research in other markets is required. Therefore, this research aims to complement the work of Shi et al. (2016a) by examining provider perspectives within the developed nation of New Zealand. In this way, the research also provides further empirical evidence as to the pathways that providers see as being beneficial to the development of 3PP services and strengthens the use of transaction cost economics within procurement research. Additionally, Shi et al. (2016b) examined outsourcing of procurement from the customers' perspective in the New Zealand market. As the current research also focuses on New Zealand, it adds to the logistics outsourcing research within this market.

The rest of this paper is organized as follows. Next, we provide an overview of the application of outsourcing of transaction cost economics (TCE) as applied in supply chain research. We position this research in relation to previous outsourcing literature and examine logistics outsourcing in the context of New Zealand. Then, a research model is presented that forms the basis for the survey methodology. We explain the survey methodology and analysis. Next, we present our findings, with a focus on uncertainty, transaction size, frequency, and asset specificity and how these factors are related to the potential to develop value for 3PL clients. The manuscript then concludes with a focus 
on how these theories can be further examined in future research, emphasizing that this research is not dyadic in nature as it only accounts for 3PL provider perspectives.

\section{Literature review}

This research is based on the theory of TCE and the outsourcing of logistics and procurement. This section presents these concepts and explains the intersection of these research streams.

\subsection{Transaction cost economics in the supply chain}

The foundation of the TCE approach is the impact that transaction characteristics have on the most appropriate governance structure, whether a market, hierarchy, or alliance (Williamson, 1975). In this way, it connects economics with organizational theory and contract law (Gibbons, 2010; Williamson, 1985). Due to the emphasis on costs associated with these exchange relationships, TCE suggests the most appropriate governance structure within which transactions occur. The key focus is on making the 'make' vs. 'buy' decision for goods or services; the 'make' option emphasizes internal supply while the 'buy' alternative seeks to secure the required resource externally. TCE has been an important influence in the analysis of the make or buy decision in services (Grover \& Malhotra, 2003; Holcomb \& Hitt, 2007; Stratman, 2008). In particular, the role of transaction costs on logistics outsourcing has a rich history (Adobor \& McMullen, 2014; Bienstock \& Mentzer, 1999; Hanna \& Maltz, 1998; Maltz, 1993, 1994; Reeves, Caliskan, \& Ozcan, 2010)

The inclusion of the TCE perspective into research on 3PLs has widened the focus of research by ensuring elements of human behavior, as well as economic theory, are considered. The key behavioral assumptions that influence transactional challenges are bounded rationality and opportunism. Bounded rationality emphasizes decision-makers’ difficulties in holding and evaluating all complexities relating to decisions. Opportunism refers to how decision-makers can act in selfinterest and guile, often taking advantage of an emerging situation to suit their needs.

The economic considerations of TCE include the concepts of asset specificity, uncertainty, and frequency. Asset specificity focuses on the amount of customization associated with given transactions; a significant customization that is unavailable or of less value to other transactions the firm engages in (McIvor, 2009) represents highly asset-specific investments. At a highly standardized level in relationship to transactions, we can say that assets are non-specific. They can also be idiosyncratic when they are related to particular organizations; alternatively, they can be of a 'mixed' nature, incorporating some form of standardization and customization around the transactions. The particular costs associated with asset specificity can relate to the human resources 
as an asset (e.g., due to specialization of knowledge that supports the transaction); site specificity (e.g., importance of a given location), or the actual physical assets (e.g., complexity of the customization of equipment used in the transaction). Therefore, firms consider a range of “relationship-specific investments [including] development of tailormade designs and acquisition of firm-specific skills” (Ellingsen \& Johannesson, 2004, p. 475) that contribute to asset-specificity.

Asset specificity influences governance choice particularly with consideration of opportunistic behavior. When several trading partners make investments in assets specific to their transactions, it increases the likelihood of an opportunistic outcome. The investments create quasi-rents, subject to the hold-up problem (Klein et al., 1978). In contrast, when there is a high frequency of transactions and greater certainty, the transactions are more likely to be governed by a market transaction.

Operational concepts of asset utilization and economies of scale are also considered important (Bienstock \& Mentzer, 1999). As frequency increases, the fixed cost per transaction can be reduced. When asset specificity and uncertainty are lower, the transactions are fairly frequent and can be managed by the market (McIvor, 2009). Transaction size is important as a control variable, as it influences the economies of scale of transactions (Verwaal \& Donkers, 2003). Considering TCE, if an organization can purchase a standard product from a supplier who supplies similar items to other customers, the supplier can achieve the lowest material or product cost based on its total leverage (Ellram \& Billington, 2001). As the costs of transaction-specific investments can "be easier to recover for large transactions of a recurring kind” (Williamson, 1985, p. 60), transaction size and frequency are important variables.

Of these influencing factors, Williamson (1981) argues that the asset specificity variable may have the greatest explanatory power regarding governance structure. When asset specificity is high, the tendency is to elect to use firm governance because the specific assets are costly to re-deploy in other uses (Gibbons, 2010).

TCE has been a productive lens with which to analyze the services offered by 3PLs. Hanna and Maltz (1998) examined 3PL expansion into warehousing and showed that increasing asset specificity is related to a higher possibility of the 'make' decision, that is, warehouse ownership. Logistics carriers should go beyond transportation and into warehousing as it allows the opportunity to develop specific assets and knowledge that enhance the long-term relationship with customers. Bienstock and Mentzer (1999) analyzed the outsourcing decision for motor carrier transportation. Considering the total of transportation and transaction costs under high uncertainty and asset specificity, common carriers are comparatively more efficient than private carriers. Human asset specificity is positively related to the level of private fleet use (Maltz, 1993). Maltz (1994) conducted an analysis of third- 
party warehousing, noting that asset specificity is negatively related to outsourcing, but frequency is positively related to outsourcing. Yang and Zhao (2016) demonstrated that integration improves logistics outsourcing relationships. Under the case of demand uncertainty, the presence of contracts can curb opportunism, but the application of contracts can aggravate opportunism (Huo et al., 2015)

\subsection{Outsourcing of procurement and aggregation of purchasing volumes}

While there has been a significant body of work on outsourcing in general, little work has focused on the potential benefits and challenges of the outsourcing of the procurement function. There was an early recognition that outsourcing of the supply management function could benefit firms' acquisition of both strategic and non-strategic components for manufacturing (Maltz \& Ellram, 1999). Later, it was recognized that the same organizational apparatus and processes used to purchase goods can be adapted for purchasing services, with a focus on either cost or value (Ellram et al., 2007).

The consolidation of purchasing activities, increasing the purchasing volume, has been widely practiced (Ellram \& Billington, 2001) to reduce purchasing costs, under terms including cooperative, group, or consortium purchasing (Tella \& Virolainen, 2005). Nollet and Beaulieu (2005) define a purchasing group as a formal or virtual structure that helps the consolidation of purchases for many organizations. Fundamental to group purchasing is combining purchasing orders where there are similarities (Schotanus \& Telgen, 2007). The consolidation of orders denotes that a central entity becomes responsible for a range of purchasing activities, for example, bidding, supplier evaluation, negotiation, and contract management activities. Such consolidation effectively leads to improved negotiation and therefore better prices than a member of the purchasing consortium could achieve, if they acted independently (Rozemeijer, 2000).

Outsourcing the procurement function enables firms to transfer processes, resources, and infrastructure used to support purchasing to the third party, delivering significant cost savings (Fernandez \& Kekale, 2007). Despite the early and growing interest in procurement outsourcing (Atkinson, 2006; Zheng et al., 2007), the implementation and adoption of procurement outsourcing traditionally have been slow (Fernandez \& Kekale, 2007). Only in recent years have 3PLs, already specializing in providing services, realized their ability to offer a wider range of value-added services including procurement capabilities (Shi et al., 2016a). The opportunity to benefit from these services has been recognized by both the providers (Shi et al., 2016a) and users or customers (Shi et al., 2016b).

Collaborative, group-buying scenarios should reduce transaction costs for members (Coase, 1937). Building a cooperative structure means putting together two or more purchasing companies at the 
same level of the supply chain to increase purchasing volume. According to transaction cost theory, such cooperation exists because of the use of markets or the price mechanism to resolve transaction imbalances (Tella \& Virolainen, 2005). If the market fluctuates with moderate or high uncertainty, the purchasing firm may not want to integrate vertically (Tella \& Virolainen, 2005). Therefore, a form of cooperation is necessary. There is a broad range of various hybrid institutions between the market and hierarchy. While consortium members may want to control their manufacturing and marketing capabilities (market-based relationships), they can combine their power of procurement (hierarchical steering). Symbiotic relationships can co-exist in the hybrid institution (Eßig, 1999) as group members participate to reduce overall transaction costs (Williamson, 1985). The nature of the product or service is also important, as many firms are reluctant to outsource strategic items/services to a third party (Fernandez \& Kekale, 2007)

From a supply chain perspective, introducing 3PP services can change the 3PL relations within a supply chain. Traditionally, most 3PL providers have contract relationships with their clients (Zhou et al., 2008). Including a procurement service can be advantageous for 3PL providers as it supports value creation for clients. 3PP usually provides additional power, through economies of scale, to 3PL providers in the negotiation with suppliers. Positioned within a network so they connect upstream and downstream players in the supply chain, 3PL providers can benefit from offering 3PP services. The 3PL providers benefit from homogeneity among customers' interests and can use these economies of scale to achieve price reductions during purchasing due to the consolidation of customers' orders (Williamson, 1985). Providers gain further transaction-cost benefits through standardization of purchasing strategies and processes (Tyndall et al., 1998). 3PP activities should also improve utilization of their logistics facilities (Chapman et al., 1998).

\subsection{Outsourcing activities within the New Zealand context}

A comprehensive analysis of outsourcing activities and 3PL providers in New Zealand is unavailable. An early figure provided by Sankaran, Mun, and Charman (2002) indicated that in 1999, 15\% of firms outsourced some part of their logistics activities. This figure was corroborated by the estimate from Light (2001) that 11\% of New Zealand businesses contracted out their distribution at this time. While the market penetration for 3PL has been relatively small in New Zealand (NZBusiness, 2009; Sankaran et al., 2002), internationally it has been much higher in other developed economies. During the early 1990s, Western European firms indicated either an extensive or moderate commitment to 3PLs of 78\%; in the USA, this figure was 46\% (Lieb et al., 1993). Later estimates in 1997 of logistics outsourcing rates reported by Millen et al. (1997) were for the USA (37\%), Western Europe (75\%), and Australia (64\%). More recently, there has also been a greater use of 3PLs throughout the 
Asian region than in New Zealand. While Indian firms in 2006 reported about 55\% use of 3PLs (Sahay \& Mohan, 2006), 60.3\% of Singaporean firms and 67.7\% of Malaysian firms reported using 3PLs (Sohail et al., 2006). Therefore, while the New Zealand penetration rate was historically much lower, we would expect this to increase over time, as the trade-off between inventory holding costs and transport economies of scale indicate there will be an increasing trend towards the use of 3PLs (Bhatnagar \& Teo, 2009). The trend towards outsourcing logistics is further supported as 3PLs are better positioned to manage the costs of multiple small deliveries in urban areas (Sankaran \& Wood, 2007).

While outsourcing rates clearly differ between regions, the reasons for outsourcing logistics activities are also shown to differ (Sohal \& Rahman, 2013). One reason that may contribute to the lower uptake of logistics outsourcing in New Zealand is the reported way that many "Kiwi [New Zealand] companies feel the need to sit on top of their stock and be able to touch it” (NZBusiness, 2009, para. 16). If such an attitude were widely spread over the community, it would certainly contribute to the lower outsourcing of logistics activities. Despite this attitude, the New Zealand market remains fiercely competitive with many 3PLs electing to compete on price (Sankaran, 2000).

With regards to the outsourcing of procurement in the New Zealand context, the study by Shi et al. (2016b) provides a perspective on how customers perceive this type of service. Shi et al. note that customers and SMEs are likely to be attracted to the reduction in costs from 3PP services. However, they show no significant relationship (as perceived by customers) between either transaction frequency, size, or asset specificity and the development of the outsourced procurement service. In contrast, the results presented by Shi et al. indicate that customers perceive that uncertainty is closely connected to the use of a 3PP service.

\subsection{Research gap}

In this context, it appears evident that there remains a research gap regarding both procurement outsourcing research and outsourcing in New Zealand. The involvement of a third party, beyond the buyer and supplier of products or services, is necessary for procurement outsourcing; we consider 3PP to be a subset of general procurement outsourcing, where a 3PL offers the service alongside their traditional logistics offerings. Therefore, this research is motivated by the increasing interest in purchasing outsourcing (Zheng et al., 2007), coupled with the increasing awareness that 3PL providers can play a greater role in supply chains by providing more value-added services (Langley, 2016; Shi et al., 2016). The opportunity to develop value-added services is particularly important in New Zealand, where the logistics outsourcing rates lag those experienced in comparable international markets. 


\section{Conceptual model and hypotheses}

Several studies have used transaction cost economics as a theoretic lens to examine and analyze 3PL providers and the services offered (Bienstock \& Mentzer, 1999; Hanna \& Maltz, 1998; Maltz, 1993, 1994). Because TCE allows analysis at the transaction-level (Williamson, 1981, 1985), it can, therefore, be applied to specific transactions in the outsourcing decision with supply chain research (Williamson, 2008). However, much of the empirical management-oriented research in the supply chain literature focuses on the analysis of survey responses from respondents where they report their answers as relevant to the firm as a whole or in terms of the relationship with a specific supplier. Under these circumstances, the survey questions can be informed by TCE principles, such as the role of uncertainty, asset specificity, or opportunism, and with the implications relating more broadly to the firm and how they structure these transactions. Examples of this stream of research that examines TCE at the firm-level includes examining supplier customization as explained by transaction costs, based on the relationship with an online supplier (Devaraj et al., 2012); supplier investment in equipment specific to a given engagement (Narayanan et al., 2015); or, making personnel investments focused on a given trading partner (Handley \& Benton Jr., 2013) or expertise or technology specific to the relationship (Nyaga et al., 2010). TCE-based research can also be conducted using aggregated data; for example, Emery and Marques (2011) used TCE to frame their investigation of raw materials inventories, based on the U.S. Commerce Department's input-output accounts and the COMPUSTAT database.

When one party has specific investments that are used for a specific exchange partner, the transaction-specific assets are established (Williamson, 1985). Specific assets refer to assets that cannot be easily redeployed in another application or transferred to another customer (Ellram et al., 2008). Asset-specific investments made by a party within a transactional relationship result in higher transaction costs (Grover \& Malhotra, 2003). 3PL providers, if required to invest in more specific assets (e.g., building a new facility to support the purchasing service) to support an activity, may choose not to offer that service as the transaction risk for them will increase substantially. Meanwhile, suppliers can engage in opportunistic behavior (e.g., due to the reduction in control). The difficulty of asset-specific investments is that they represent a hold-up potential (Holmström \& Roberts, 1998). At the beginning of the transaction, 3PL providers may have multiple opportunities to select a supplier. However, once the asset-specific investments are made, the buying situation can be dramatically transformed (Williamson, 1985). 3PL providers may reduce their negotiating power during the purchase process if suppliers understand that the 3PL has few alternatives. Therefore, investment in non-redeployable and relationship-specific assets can result in opportunistic behavior, 
making it difficult for a 3PL to benefit from the economies of scale in a 3PP service. Therefore, we predict:

H1: The greater the required investments in non-redeployable assets are, the less likely are 3PL providers to offer $3 P P$ services.

\section{Uncertainty}

Uncertainty is related to the inability of a firm to confidently forecast future events. There are two sources of uncertainty: the market and the firm itself. External, market uncertainty, can result from the volatility of product availability, key suppliers, purchasing prices, and other disruptions to the market (Ellram et al., 2008). Internal uncertainty can be connected to the inability to forecast future demand. A primary source of uncertainty during decision-making is the lack of firms' capability in collecting information and using this to improve their forecast of changes in the external environment (Williamson, 1985). Meanwhile, information asymmetry (Williamson, 1985) results in the inability of 3PL providers to comprehensively understand details of suppliers as they may pursue “self-interest seeking with guile” (Williamson, 1985, p. 47). Therefore, information asymmetry increases the scope for opportunism (Lonsdale, 2001). If there are higher levels of uncertainty, therefore, 3PL providers may be less able to provide a consistent service at reasonable cost. Therefore, we predict:

H2: The lower the level of uncertainty is, the more likely are 3PL providers to offer 3PP services.

\section{Frequency}

Frequency refers to the extent to which certain events recur. If 3PL providers offer few purchasing services and shipments, 3PL users may not receive adequate benefits. While customers may be disinclined towards the use of a 3PP service when they have frequent transactions (Shi et al. 2016b), greater frequency of transactions may be attractive to the providers. Based on TCE, purchasing leverage is possible for recurrent transactions conducted with the same supplier (Ellram \& Billington, 2001). Where there is the opportunity to manage a high frequency of transactions and collect similar orders for customers, the provider will gain economies and will therefore be more likely to favorably perceive other transactions and benefit from introducing a 3PP service. Therefore, we hypothesize:

H3: The greater the economies from transaction frequency are, the greater is the likelihood of 3PL providers offering $3 P P$ services. 


\section{Transaction size}

According to TCE, the transaction size determines the economies of scale of transactions (Williamson, 1985). Larger transaction size can increase a firm’s purchasing power (Ramsay, 1994). By consolidating orders from multiple 3PL users, 3PL providers can exert leverage in negotiation with suppliers. Consolidation of orders can result in improved terms of trade and lower unit costs and prices, coupled with more sophisticated contracts with suppliers. Where there is the opportunity to consolidate orders and therefore gain economies from doing so, 3PLs are more likely to be able to benefit from providing additional 3PP services. Therefore, we hypothesize:

H4: The greater the economies from transaction size are, the greater is the likelihood of 3PL providers offering $3 P P$ services.

\section{Value-to-client}

Outsourcing procurement to 3PL providers can bring some benefits to 3PL users in the form of a new governance structure. 3PL users can focus on their core competencies and outsource the purchasing functions for non-critical items. They may aggregate their purchasing power via 3PL providers since most 3PL users, such as small- and medium-sized enterprises (SMEs), struggle with the purchasing price due to their low levels of purchasing power (Hudson \& McArthur, 1994). Enterprises in New Zealand tend to be SMEs, with 97\% of firms employing 19 or fewer people (Ministry of Economic Development, 2011). Particularly in New Zealand, most 3PL users are SMEs located a considerable distance from their primary suppliers and markets in Europe, North America, and Asia. This geographic barrier adds a burden to 3PL users in their supply chain management practices (Wilson \& Roy, 2009) and interfaces with key suppliers and customers in the supply chain. By providing procurement expertise, 3PL providers can bring economies of scale to the SME clients in New Zealand and provide them with higher levels of procurement standardization and expertise than they would otherwise invest in. Therefore, we hypothesize:

H5: The greater the likelihood of 3PL providers offering a $3 P P$ service is, the greater is the perceived value to $3 P L$ clients.

Therefore, this research focuses on 3PL providers' perceptions relating to the factors that influence the adoption of 3PP as a new, value-added service. Four constructs and the relationships 
between these are used in this research as follows: asset specificity, uncertainty, frequency, and transaction size. Figure 1 depicts the conceptual model that guides this research.

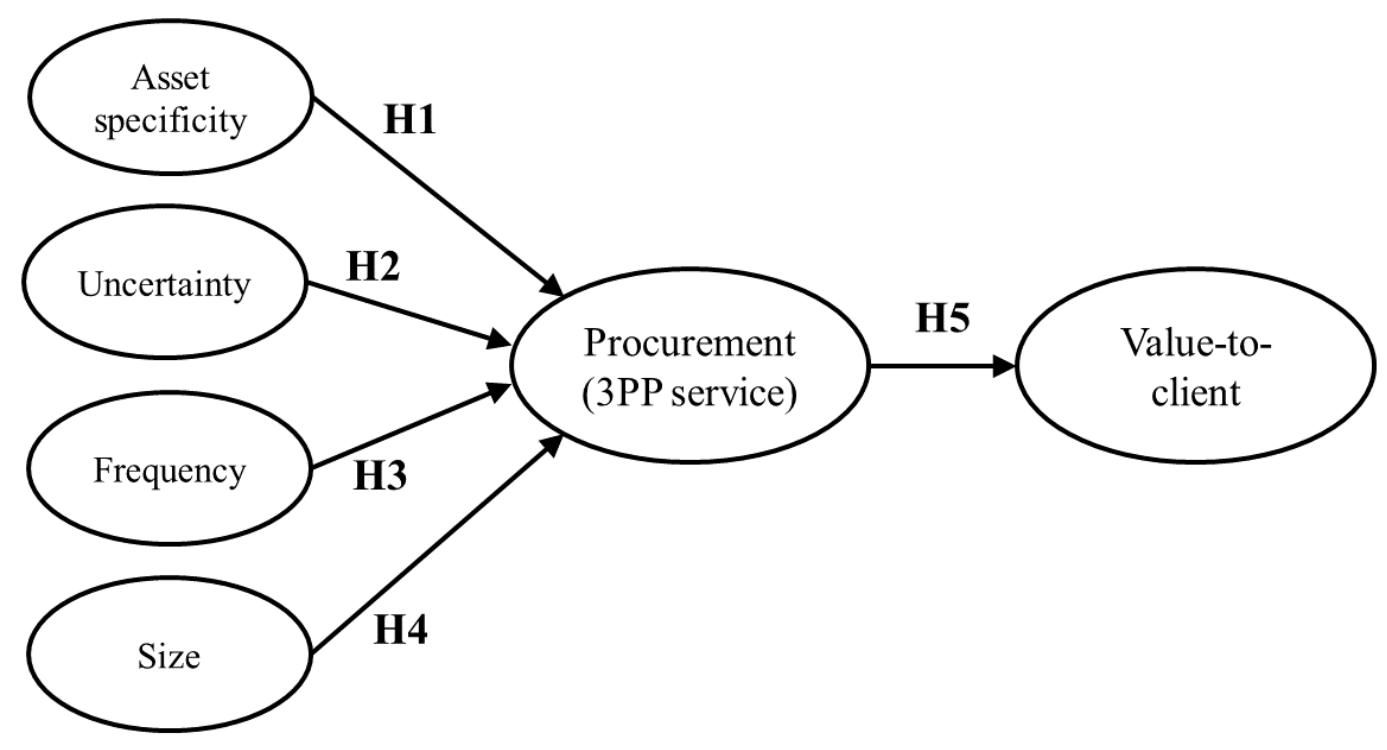

Figure 1 A conceptual model for third party purchase (3PP) services 


\section{Research methodology}

To test the model, a structural equation modeling approach was chosen as it enables evaluation of the model in its entirety and will allow us to answer the research questions.

\subsection{Survey instrument}

The designed questionnaire was used to test the proposed model. The questionnaire was developed in two stages. First, a review of the existing literature offered the foundation of survey development. Second, the paper-based questionnaire draft was discussed with three academic colleagues to improve the comprehensibility of the questions, ensuring more valid responses would be received from business professionals. After some minor changes, the questionnaire was discussed with five middle and senior logistics or purchasing managers. The questionnaire was further refined based on their comments. Reviews by both academics and practitioners were to offer face validity (Cook \& Campbell, 1979). Electronic and web-based questionnaires were used to collect the data. A copy of the survey instrument is provided in the Appendix.

\subsection{Measures}

The scales of asset specificity were measured by coordination with 3PL providers, investments in purchasing resources (e.g., time and effort), ability in leveraging purchasing function, and transferring organization routines and working procedures (Rabinovich et al., 2007; Skjoett-Larsen, 2000). We adopted the uncertainty measures from Rabinovich et al. (2007) and Reeves et al. (2010) to capture uncertainty based on the ability of demand forecasting, returning value to the organization, levels of evaluating purchasing performance, and duration of outsourcing purchasing services. The scales of frequency were measured by the variables of costs and levels of negotiation power to reduce purchasing costs (Ellram \& Billington, 2001; Goldsby \& Eckert, 2003; Hanna \& Maltz, 1998; Maltz, 1993). We measured transaction size by the ability to combine purchasing orders, the degree of user consolidation, and benefits associated with the size of orders (Ellram \& Billington, 2001; Gattorna et al., 1991; Stump, 1995).

We adopted the measures of 3PP services based on a classification of the purchasing function into the following activities: category management, supplier market research, supplier qualification and selection, request for proposal management, bid preparation and management, cost analysis, and supplier relationship management (Andersson \& Norrman, 2002; Rozemeijer, 2000; Emiliani, 2000; Presutti, 2003; Van Weele, 2010). These are more comprehensive services that move beyond a simple purchasing transaction. The scales relating to value-to-client were measured according to the 
ability of 3PP services to aid in core competencies, maintain relationships with 3PL customers, and minimize relevant purchasing risks (Hofer et al., 2009; Sink \& Langley, 1997).

\subsection{Data collection}

The data collection in this study was supported by the Chartered Institute of Logistics and Transport (CILT) New Zealand and the Centre for Supply Chain Management in New Zealand. The members of these associations are professionally qualified and have practical work experience in logistics and purchasing. The associations did not permit us to collect a variety of personal demographic information from respondents (e.g., managerial position occupied and highest qualification). However, to ensure data quality, we imposed three requirements on the survey respondents to ensure that they had sufficient knowledge of purchasing, logistics, and their companies' operations. First, respondents were required to be at the middle management level or higher, preferably, Chief Executive Officer (CEO), Procurement Officer (CPO) or Chief Operations Officer (COO). Second, respondents were required to have at least three years of work experience associated with purchasing and logistics. Third, respondents were required to have a professional qualification related to purchasing and logistics. An online survey link (including electronic documents) with cover letters explaining the purpose of the research was advertised on the official association websites, and the associations used their newsletters and e-mails to encourage members to participate in the surveys. We obtained the contact details for the members of the Centre for Supply Chain Management (CSCM) with the permission of the director. Also, we privately contacted several logistics companies' managers (e.g. CEO, COO, or CPO) in advance, and they helped us to complete the questionnaire by email.

We received 166 usable responses from 3PL providers (a response rate of 26.6\%). This response rate is comparable to other reported response rates under similar circumstances (23.1\% response rate by Panayides and So [2005]; 22\% response rate by Rahman [2008]; 14.8\% response rate by Cousins et al. [2006]). Thus, the response rate was considered satisfactory.

\subsection{Non-response bias and common methods bias}

We examined whether there was non-response bias and common-method variance (CMV) in the response data using the approach suggested by Armstrong and Overton (1977) and Podsakoff and Organ (1986). We compared the first and last $10 \%$ of respondents based on demographic variables (years partnered with 3PL customers, firm size, and annual gross sales) and by using a $t$-test, which revealed no statistically significant difference between the two groups. These results provided us with confidence that non-response bias was not an issue in this research. 
The Harman one-factor test was conducted to test the presence of CMV (Podsakoff \& Organ, 1986). All items making up the constructs were used in a principal component analysis (PCA) model with Varimax rotation (Gotzamani et al., 2010). The Kaiser-Meyer-Olkin (KMO) measure of sampling adequacy for 3PL providers was 0.798, higher than the required threshold of 0.5 (Kaiser, 1970). The Bartlett's Test of Sphericity was significant $(p<0.001)$ (Bartlett, 1950), suggesting suitability for factor analysis. Seven factors were extracted accounting for $65.8 \%$ of the variance with the first factor accounting for $14.5 \%$ of the variance. The Harman one-factor test confirmed that CMV was not a problem with the data.

\section{Analysis and discussion}

\subsection{Respondent profiles}

Table 1 Company profile

\begin{tabular}{|c|c|c|}
\hline Firm Characteristics & Firm Group & $\begin{array}{c}\text { Percentage } \\
\text { (3PL providers) }\end{array}$ \\
\hline \multirow{5}{*}{$\begin{array}{l}\text { Age of firms partnered with 3PL } \\
\text { users }\end{array}$} & Less than or equal to 2 years & 3.6 \\
\hline & More than 2 years but less than or equal to 5 years & 7.2 \\
\hline & More than 5 years, but less than or equal to 10 years & 22.9 \\
\hline & More than 10 years, but less than or equal to 15 years & 35.5 \\
\hline & More than 15 years & 30.7 \\
\hline \multirow[t]{6}{*}{ Number of employees } & Less than 50 & 6 \\
\hline & $51-100$ & 6.6 \\
\hline & $101-500$ & 21.7 \\
\hline & $501-1000$ & 24.7 \\
\hline & $1001-2000$ & 26.5 \\
\hline & Over 2000 & 14.5 \\
\hline \multirow[t]{5}{*}{ Annual gross sales } & Less than or equal to NZ\$ 5 million & 1.8 \\
\hline & More than NZ\$ 5 million, but less than or equal to NZ\$ 10 million & 10.2 \\
\hline & More than NZ\$ 10 million, but less than or equal to NZ\$ 15 million & 22.3 \\
\hline & More than NZ\$ 15 million, but less than or equal to NZ\$ 20 million & 33.7 \\
\hline & More than NZ\$ 20 million & 31.9 \\
\hline
\end{tabular}

The demographics of the surveyed 3PL providers is presented in Table 1 . In total, $65.6 \%$ of the informants indicated that they had been in the 3PL business for 2-15 years; 30.7\% of 3PL providers had partnered with their customers for more than 15 years. Around 6\% employed less than 50 fulltime employees and $87.9 \%$ of 3PL providers indicated that the annual gross sales exceeded NZ\$10 million.

The importance of outsourcing services as perceived by 3PL providers is illustrated in Table 2. Transportation and warehousing services were regarded as the most important outsourcing services. Also, more than half of the informants indicated that purchasing could be rated as an important 
service. However, the services of managing product returns and order management were equally rated as the least important services.

Table 2 Perceived level of importance of logistics activities performed by 3PL providers

\begin{tabular}{lc}
\multicolumn{1}{c}{ Activity } & $\begin{array}{c}\text { Percentage } \\
\text { (3PL providers) }\end{array}$ \\
\hline Transportation & 91.57 \\
Warehousing & 84.34 \\
Purchasing & 67.47 \\
Consolidation and distribution & 63.86 \\
Inventory management & 58.43 \\
Product returns & 53.01 \\
Order management & 53.01 \\
Cross docking & 54.22 \\
Packaging & 58.43 \\
\hline
\end{tabular}

\subsection{The measurement model}

After data collection, we performed a series of tests to analyze the reliability and validity of the constructs. We used version 19 of SPSS and AMOS for the statistical analysis.

\subsubsection{Unidimensionality and reliability}

Two-step methods were used to test the construct reliability (Narasimhan \& Jayaram, 1998). First, unidimensionality of the scales was examined by using exploratory factor analysis (EFA). Second, the data reliability was assessed by using Cronbach's Alpha ( $\alpha$ ). EFA with Varimax rotation was used to determine the major constructs measured by the items. Cronbach's Alpha $(\alpha)$ was used to assess the internal consistency of each construct (Nunnally, 1978). We computed Cronbach’s Alpha $(\alpha)$ for each construct to test for internal consistency.

Table 3 shows that each construct in the sample of 3PL providers had at least three measured variables to be explained. All the factor loadings were above 0.5 (Hair et al., 2014). 
Table 3 Exploratory factor analysis for New Zealand 3PL providers

\begin{tabular}{|c|c|c|c|c|c|c|c|}
\hline & \multicolumn{7}{|c|}{ 3PL Providers } \\
\hline & Procurement & $\begin{array}{c}\text { Benefit to } \\
\text { 3PL provider }\end{array}$ & $\begin{array}{c}\text { Asset } \\
\text { specificity }\end{array}$ & $\begin{array}{c}\text { Value to } \\
\text { client }\end{array}$ & Size & Uncertainty & Frequency \\
\hline NL-Cord & .063 & .119 & .734 & .259 & .073 & .175 & .037 \\
\hline NL-Inves & .032 & .082 & .824 & -.024 & -.035 & .074 & .129 \\
\hline NL-Leve & .030 & .123 & .569 & -.180 & .429 & .263 & -.070 \\
\hline NL-Rout & .015 & -.023 & .847 & -.078 & -.022 & .061 & .172 \\
\hline NL-Demo & -.094 & .044 & .437 & .150 & .091 & .615 & -.004 \\
\hline NL-Conf & .308 & -.013 & .012 & .116 & .113 & .716 & .074 \\
\hline NL-Eva & .047 & .187 & .229 & .050 & -.078 & .691 & .010 \\
\hline NL-Period & .187 & .072 & .026 & .027 & .184 & .695 & .326 \\
\hline NL-Fix & .174 & .122 & .077 & .149 & .161 & .354 & .561 \\
\hline NL-Moni & .222 & -.002 & .192 & .098 & .159 & .038 & .725 \\
\hline NL-FreInc & .027 & .304 & .162 & .150 & .323 & .101 & .570 \\
\hline NL-PurcOrd & .129 & .099 & .012 & .069 & .698 & .118 & .139 \\
\hline NL-Conso & .075 & .088 & -.039 & .213 & .854 & .112 & .053 \\
\hline NL-OrdLag & .160 & .085 & .113 & .092 & .683 & -.054 & .235 \\
\hline NL-PA-Cat & .708 & .172 & .086 & .021 & -.086 & .086 & .200 \\
\hline NL-PA-Mgk & .730 & .140 & .009 & .076 & .029 & .114 & .110 \\
\hline NL-PA-Qua & .673 & .121 & .085 & .084 & .151 & .081 & .171 \\
\hline NL-PA-Pro & .715 & -.117 & -.148 & .134 & .191 & -.021 & .119 \\
\hline NL-PA-Bid & .760 & .006 & -.074 & .231 & .086 & .066 & .169 \\
\hline NL-PA-Cos & .718 & .252 & .117 & .106 & .014 & .144 & -.137 \\
\hline NL-PA-Sup & .740 & .208 & .076 & .177 & .186 & .068 & -.173 \\
\hline NL-Risk & .217 & .110 & -.054 & .820 & .126 & .147 & .168 \\
\hline NL-MaiRel & .164 & .213 & .066 & .793 & .161 & .105 & .058 \\
\hline NL-CorBus & .307 & .235 & .039 & .775 & .097 & .055 & .114 \\
\hline $\begin{array}{l}\text { Total variance } \\
\text { explained }\end{array}$ & & & & $65.79 \%$ & & & \\
\hline
\end{tabular}

In the confirmatory factor analysis (CFA) model, we used maximum-likelihood estimation to justify the factor structure. Usually, $\chi^{2}$ value and degrees of freedom, normed Chi-Square, comparative fit index (CFI), and root mean square error of approximation (RMSEA) provide sufficient information to evaluate the overall model (Hair et al., 2010). Additionally, the values of the incremental fit index (IFI) and Tucker-Lewis fit index (TLI) are generally reported. CFI and TLI above 0.9 are usually associated with a model that fits well. Also, lower RMSEA values indicate better fit, usually at below 0.08, although an absolute cut-off for RMSEA is debatable (Hair et al., 2014).

The model fit indices for 3PL providers were $\chi^{2}(352)=540.145, \mathrm{p}<0.001$; the normed ChiSquare $=1.535 ; \mathrm{CFI}=0.91 ; \mathrm{IFI}=0.91 ; \mathrm{TLI}=0.90 ;$ and, $\mathrm{RMSEA}=0.057$, indicating that both models were acceptable. All factor loadings were greater than 0.50 and highly significant at $p$-value less than 0.001 (Hair et al., 2014). 
Table 4 illustrates the values of Cronbach's Alpha ( $\alpha$ ), composite reliability (CR), and variance extracted from the sample of 3PL providers. All Cronbach's Alpha $(\alpha)$ and CR were above 0.70, considered to be within an acceptable range according to Nunnally (1978), and the values of variance extracted were greater than 0.50 . Therefore, convergent validity was established.

Table 4 Cronbach's Alpha $(\alpha)$ and composite reliability for New Zealand 3PL providers

\begin{tabular}{|c|c|c|c|c|c|}
\hline Construct & Indicator & $\begin{array}{c}\text { Standardized } \\
\text { weight }\end{array}$ & $\begin{array}{c}\text { Cronbach's } \\
\text { Alpha ( } \alpha) \\
\end{array}$ & $\begin{array}{c}\text { Composite } \\
\text { reliability }\end{array}$ & $\begin{array}{c}\text { Variance } \\
\text { extracted }\end{array}$ \\
\hline \multirow[t]{4}{*}{ AS } & NLRout - AS & 0.793 & 0.789 & 0.828 & 0.549 \\
\hline & NLLeve - AS & 0.611 & & & \\
\hline & NLInves - AS & 0.816 & & & \\
\hline & NLCord - AS & 0.765 & & & \\
\hline \multirow[t]{4}{*}{ UN } & NLPeriod - UN & 0.756 & 0.805 & 0.814 & 0.525 \\
\hline & NLEva - UN & 0.755 & & & \\
\hline & NLConf - UN & 0.783 & & & \\
\hline & NLDemo - UN & 0.613 & & & \\
\hline \multirow[t]{3}{*}{ FR } & NLFreInc - FR & 0.694 & 0.735 & 0.773 & 0.533 \\
\hline & NLMoni - FR & 0.785 & & & \\
\hline & NLFix - FR & 0.697 & & & \\
\hline \multirow[t]{3}{*}{ SZ } & NLOrdlag - SZ & 0.682 & 0.733 & 0.796 & 0.570 \\
\hline & NLConso - SZ & 0.879 & & & \\
\hline & NLPurcOrd - SZ & 0.641 & & & \\
\hline \multirow[t]{7}{*}{ PROCU } & NLPAQua - PROCU & 0.761 & 0.872 & 0.893 & 0.546 \\
\hline & NLPAMgk - PROCU & 0.744 & & & \\
\hline & NLPACat - PROCU & 0.721 & & & \\
\hline & NLPAPro - PROCU & 0.721 & & & \\
\hline & NLPABid - PROCU & 0.651 & & & \\
\hline & NLPACos - PROCU & 0.803 & & & \\
\hline & NLPASup - PROCU & 0.831 & & & \\
\hline \multirow[t]{3}{*}{ VTC } & NLCorbus - VTC & 0.848 & 0.862 & 0.896 & 0.742 \\
\hline & NLMaiRel - VTC & 0.767 & & & \\
\hline & NLRisk - VTC & 0.855 & & & \\
\hline
\end{tabular}

\subsubsection{Validity}

Fornell and Larcker (1981) proposed a rigorous validity test that compares the average variance extracted (AVE) values for any two constructs with the square of the correlation estimate between these two constructs. The test is based on the notion that a latent construct should explain more of the variance in its item measures that it shares with another construct.

In Table 5, the diagonal values are variance extracted. We compared the AVE values for any two constructs with the square of the correlation estimate between these two constructs. According to the computations, items assigned to one construct were not significantly loaded on others. Thus, discriminant validity was established. 
Table 5 Discriminant validity for New Zealand 3PL providers

\begin{tabular}{|l|l|l|l|l|l|l|}
\hline & \multicolumn{1}{|c|}{ AS } & \multicolumn{1}{c|}{ UN } & \multicolumn{1}{c|}{ FR } & SZ & PROCU & VTC \\
\hline AS & 0.549 & & & & & \\
\hline UN & $0.391^{* * *}$ & 0.525 & & & & \\
\hline FR & $0.403^{* * *}$ & $0.350^{* * *}$ & 0.533 & & & \\
\hline SZ & $0.101^{*}$ & $0.344^{* *}$ & $0.486^{* * *}$ & 0.570 & & \\
\hline PROCU & $0.154^{*}$ & $0.420^{* * *}$ & $0.377^{* * *}$ & $0.305^{*}$ & 0.546 & \\
\hline VTC & $0.081^{* *}$ & $0.370^{* * *}$ & $0.482^{* * *}$ & $0.451^{* * *}$ & $0.407^{* * *}$ & 0.742 \\
\hline
\end{tabular}

Note: $* P<0.05 * * P<0.01 * * * P<0.001$

\subsection{Structural equation modeling results}

Based on the overall assessment of the measurement model, the next step focused on the structural model to test the hypothesized relationships. AMOS 19 was used to assess the individual hypotheses by reviewing the direction and significance in the AMOS output.

The model fit indices showed that the hypothesized structural model achieved acceptable fit for the sample data $\left(\chi^{2}(365)=655.156, \mathrm{p}<0.001\right.$; the normed Chi-Square $=1.795$; CFI $=0.86$; IFI = 0.86; TLI $=0.85$; and, RMSEA = 0.069). AMOS outputs on the hypothesized paths' standardized regression weights with relevant critical ratio and p-values were then examined to test the individual hypotheses. Table 5-28 provides the results of the structural model test.

In the sample of 3PL providers, uncertainty, frequency, and size had a significant impact on procurement $(\beta=0.32, \mathrm{p}<0.01 ; \beta=0.33, \mathrm{p}<0.01 ; \beta=0.201, \mathrm{p}<0.05$ respectively). These results confirmed our hypotheses for H2a, H3a, and H4a. However, the relationship between asset specificity and procurement was not significant $(\beta=-0.084, \mathrm{p}=0.33)$, suggesting no support for $\mathrm{H} 1$. The path from procurement to value-to-client was highly significant $(\beta=0.588, \mathrm{p}<0.001)$. Thus, H5 was supported.

Table 6 Hypothesized paths testing for New Zealand 3PL providers

\begin{tabular}{clcccc}
\hline Path & & $\begin{array}{c}\text { Standardized } \\
\text { weight }\end{array}$ & CR & $\boldsymbol{p}$ & Note \\
\hline H1 & Asset specificity $\rightarrow$ Procurement & -0.084 & -0.974 & 0.33 & Not significant \\
H2 & Uncertainty $\rightarrow$ Procurement & 0.32 & 3.015 & $0.003<0.01$ & Supported \\
H3 & Frequency $\rightarrow$ Procurement & 0.33 & 3.211 & $0.001<0.01$ & Supported \\
H4 & Size $\rightarrow$ Procurement & 0.201 & 1.992 & $0.046<0.05$ & Supported \\
H5 & Procurement $\rightarrow$ Value-to-client & 0.588 & 5.802 & $<0.001$ & Supported \\
\hline
\end{tabular}




\subsection{Discussion}

This research focuses on 3PL providers in New Zealand and their ability to offer value-added services. 3PP is a viable option for these firms. This study shows that most 3PL providers highly rate the importance of 3PP services although such new services are not yet commonly implemented in real business contexts. Our findings offer valuable insights regarding 3PP services provided by 3PL providers based on TCE.

We found no significant relationship between asset specificity and 3PP services. This conclusion contradicts the results by Hanna and Maltz (1998) in their study of less-than-truckload (LTL) providers expanding into warehousing services. The probable reason is that 3PL providers believe that they do not need to invest significant levels of funds and resources in 3PP services dedicated to customers since the current logistics infrastructure is mature and offering 3PP services can help 3PL providers better utilize their warehouse and transportation assets. Offering a 3PP service would not require 3PL providers to invest in large, non-redeployable assets. For instance, purchasing professionals can be recruited from a free market, job fair, or 3PL customer company. They may not even need to leverage the investment into the purchase function to improve the relationships with their customers since they have already formed a trust foundation with their customers (Knemeyer \& Murphy, 2006). Having a high level of trust makes it easy for 3PLs to introduce 3PP services to their clients. In addition, 3PLs can understand the purchasing requirements of their customers' regular routines, for example, the types and volumes of products to purchase. The providers' perspectives on the importance of asset specificity reported here are similar to those identified by Shi et al. (2016b), where no significant relationship was identified by the customers of 3PLs in relation to asset specificity and their intention to use 3PP services. In both studies the standardized weight was close to zero and non-significant, indicating that both providers and customers see little relationship between asset specificity and the use of 3PP services.

We found a significant relationship between uncertainty and 3PP service development from the providers' perspective. This finding is similar to the results from Reeves et al. (2010) and Bienstock and Mentzer (1999), where the focus was specifically on outsourcing of distribution and logistics services within the automotive supplier industry. Reeves et al. (2010) showed that greater uncertainty leads to outsourcing while Bienstock and Mentzer (1999) showed that while uncertainty increases transaction costs, the outsourcing option significantly lowers overall costs to make it the preferred option. Similarly, we found that uncertainty is related to the development of the outsourcing of the procurement service to the 3PL when developing a 3PP service and so our findings are consistent with previously reported results and highlight the importance of uncertainty as a factor that 
influences the outsourcing of procurement processes. These results, from the providers' perspective, are similar to the customers' perspectives reported in Shi et al. (2016b), indicating that both sides of the outsourcing relationship see uncertainty as an important factor. The advantages of 3PP development for 3PLs include greater size, scale, and flexibility; therefore, 3PLs have a competitive edge and can bring additional business opportunities to 3PL users, enticing the customers to remain loyal to their logistics service providers for a longer period and reducing customers' uncertainty this way. By using the 3PP service, customers might reduce the impact of external uncertainties in the management of the client firm (Ellram et al., 2008).

We found a significant relationship between the economies available from frequency of transactions and the likelihood that a 3PL would develop a 3PP service. This finding is similar to the results from Hanna and Maltz (1998), whose study focused on LTL providers expanding into warehousing services. 3PL providers expect frequent orders from their clients, such as weekly or fortnightly orders, by which they can enhance their forecasting accuracy, plan purchasing volume, and control transportation capacity and inventory levels efficiently. The order frequency will impact on the value of products ordered (including the lead time from placing an order to receiving it), safety stock, and transportation costs. It is possible for 3PL providers to reduce fixed cost per transaction due to the high frequency of placing orders; the reduction in fixed cost will promote a long-term, relational approach between the organizations (Selviaridis \& Spring, 2010). By consolidating customers' orders and offering the big orders needed for increasing leverage power, 3PL providers can benefit from passing on favorable pricing to their clients. In contrast, the relationship between frequency and 3PP from the customers' side is less clear and while there is a positive weight for the relationship, it remains statistically insignificant (Shi et al., 2016b). This may be due to customers perceiving more opportunity for them to benefit from the economies of scale themselves if they keep such transactions in-house.

We found a significant relationship between economies available from large transactions and the likelihood that a 3PL would develop a 3PP service. Large transaction size gives higher priority to 3PL providers during the negotiation process. 3PL providers with large negotiation power should be able to minimize the purchasing costs and have influence on suppliers' behaviors, congruent with past research (Ramsay, 1994). 3PLs believe that economies from a large transaction size can overcome the limitations of transaction size that have previously been identified (Hudson \& McArthur, 1994). It is certain that transaction size creates downwards pressure on prices and, therefore, having a large transaction size helps 3PL providers to gain the advantage from aggregated purchasing volumes. Aggregating purchase orders is not a problem for 3PL providers since they can 
understand the past routine process of their customers and easily combine their orders to get lower purchasing prices. The aggregated orders are a significant advantage for 3PL providers to reduce the purchasing price. However, from the customers' side of the transaction, the connection between size and use of 3PP services is not as clear; while there is a small positive standardized weight, this has been is shown to be statistically insignificant (Shi et al., 2016b). This may be because customers would prefer not to outsource larger transactions as the transaction costs (on a per-item basis) would be relatively lower, reducing the benefits from outsourcing. Therefore, the providers (as reported in this study) and customers (as reported in Shi et al., 2016b) see this relationship differently.

In the hybrid context, combining the structure of market and hierarchy (Williamson, 1985, 2008), 3PL users can obtain further benefits from the expansion of services to include more value-added offerings. The outcome of our survey suggests a significant relationship between a 3PP service and value-to-client. 3PL providers think that they can help their users minimize purchasing risk. Also, the providers point out that 3PL users are able to focus on their core competency and their purchasing costs can be reduced. The costs have two components: one is direct costs, such as procurement costs, and another is indirect costs, such as appraisal costs of measuring suppliers' performance (Ferrin \& Plank, 2006). Outsourcing 3PP services offered by 3PL providers can be used to maintain good relationships with 3PL users in order to improve customer loyalty.

The perspectives of 3PL providers in this study represent one side of the transaction and this presents an interesting perspective in contrast to the customers' perspectives reported in Shi et al. (2016b). Both parties to the outsourcing relationship surprisingly see no relationship between asset specificity and the use of 3PP services. Both parties (as reported here and in Shi et al. [2016b]) see opportunities for 3PP to be valuable when there is a higher degree of uncertainty. In contrast, providers and customers have differing perspectives on the importance of frequency and size in the use of 3PP services. While customers see no significant relationship (Shi et al. 2016b), the providers' perspectives reported in the current study indicate that they see an advantage in developing and managing the 3PP relationships when there is greater size and frequency. The differences are significant and may require careful discussion between parties when outlining the development of 3PP services.

\subsection{Managerial implications}

The results of our survey allow us to claim four general relationships that 3PL managers will need to understand when developing 3PP services. First, we found that there is no relationship between asset specificity and the likelihood of 3PLs' development of 3PP services. Second, with greater uncertainty, the likelihood of 3PP service development increases. Third, greater economies from 
frequent customer transactions leads to a greater likelihood that 3PLs will develop 3PP services. Fourth, the opportunity to economize with large transactions and the ability to aggregate orders is also connected to a greater likelihood that 3PLs will develop 3PP services. From these general relationships, we draw three implications for 3PL managers. The first implication relates to the ratio of potential benefits to implementation costs or risks. One of the key costs that a 3PL might incur in establishing 3PP services is asset-specific investments; sizeable investments increases the risks to the firm. However, our respondents did not perceive that this is a necessary prerequisite for their success in developing 3PP services. Furthermore, development of 3PP services is made more attractive as while this risk is not perceived to be significant, the opportunity to benefit is substantial. Therefore, where there is a high frequency, larger size transactions, and low uncertainty, 3PLs perceive the development of 3PP as viable. In many cases, these survey results should encourage 3PL providers to develop their value-added 3PP services.

A second implication is that when establishing 3PP services, 3PLs should carefully identify key clients or market sectors to target on the initiation of the new service. 3PLs should work to establish which of their clients are likely to have a high frequency of purchases with large order sizes, coupled with low levels of uncertainty in their purchases. In the New Zealand context, this would suggest clients that are major organizations that purchase commodity-type products on a regular basis are the most logical clients for the developed 3PP services. Such requirements reflect many larger firms in the New Zealand business landscape, and particularly, agriculture firms. These opportunities indicate that where a 3PL has sufficient expertise in serving these markets, the deployment of 3PP services could be rapidly undertaken and would have a valuable benefit in developing a strong relationship with the client. However, it will take time for 3PP services in the New Zealand market to mature; some 3PL providers are not sufficiently operationally efficient. A lack of efficiency in the 3PL operations would make it difficult to develop and launch new services that are less transactionfocused. Once higher levels of efficiency are developed, however, 3PLs will have room to expand their current market by offering 3PP services to their customers.

A third implication is that 3PL providers, as third-party purchasers, believe that they can negotiate lower prices for clients through consolidating individual and small purchase orders and this will contribute to a successful relationship with their clients. In New Zealand, the majority of firms are SMEs and are therefore likely to benefit from the economies of scale that may provide them with reduced costs, allowing them to focus on core businesses, and mitigated purchasing risk. Currently, given the level of competitiveness in the New Zealand 3PL market, one could infer that 3PL providers might seek to expand their markets. 
A fourth and final implication concerns which side of the transaction 3PP services are viewed from. While past research has examined the customers' perspective of the use of 3PP services (Shi et al., 2016b), the results from the present study provide insight into the 3PL providers' perspectives. Customers do not perceive a strong relationship between frequency and the size of transactions in relationship to their interest in using a 3PP service. However, in this research, the 3PLs indicated more awareness and interest in these factors in conjunction with their intention to develop 3PP services. This will be important for 3PL providers as if they decide to develop and offer these services and focus on communicating value to the customers by emphasizing benefits from frequency and size, it may seem to be unconvincing to their customers. In contrast, both the providers (in this study) and the customers (Shi et al., 2016b) see an important relationship between uncertainty and the use of 3PP services, and therefore emphasizing this factor may be important when 3PLs and their customers discuss the development of 3PP services.

\section{Conclusions}

The 3PL market in New Zealand remains competitive and many 3PL providers continue to develop value-added services to gain competitive advantages. One example of this service is 3PP and this research has explored how 3PLs perceive the opportunities to benefit from developing this service, although it is not yet provided. The results show that there is a high level of perceived benefit to the client firms, and the 3PP service is particularly valuable where 3PLs see the opportunity to gain economies from large and frequent transactions. We found that the 3PLs perceive little need for asset specificity relating to the development of 3PP services since it is not costly for them to fulfil the purchasing function. The characteristics of New Zealand 3PL users is that they regularly buy for certain slices of the markets since they do not want to have more inventories. 3PL providers will be able to continuously offer 3PP services since the demand of market uncertainty has not changed significantly in New Zealand. Through the development of the 3PP services, providers can drive lower prices on behalf of their customers through consolidating purchase orders. Also, 3PL providers can better use their logistics facilities and reduce their operational costs through using integrated logistics systems. However, to the best of our knowledge, there are no studies dealing with 3PP services as value-added services offered by 3PL providers in New Zealand.

This research makes several key contributions. First, it is an initial study that analyzes the opportunity to develop 3PP services by 3PL providers. The demand for outsourced purchasing function has been dramatically increasing and 3PP services are a viable option for 3PL providers to improve their operations in a more effective manner, as determined from the providers' perspective. 
Second, this research applies TCE at the firm level to study the vital business function of procurement. TCE is a useful tool to aid 'make or buy' decisions. So far, many TCE studies have only been applied at the transaction level (Ellram et al., 2008; Grover \& Malhotra, 2003; Maltz, 1993, 1994; Masten, 1984; Masten, Meehan, \& Snyder, 1991; Walker \& Weber, 1987). While this is aligned with the original intent and purpose of TCE, we note that other studies have derived and tested hypotheses at the firm-level, based on relationships derived from the TCE perspective. Following this pathway, our research advances the application of TCE to inform firm-level research. Third, TCE has traditionally focused on the views of service users. However, this paper primarily focuses on the perspective of 3PL providers. 3PL providers may initiate development of 3PP services in their current market, based on their advantages (e.g., domestic and international logistics networks and financial strength); therefore, 3PLs should prioritize the development and introduction of 3PP services. Fourth, the survey results show that 3PP may not require significant asset specific investments and could, therefore, be introduced at low risk to the provider.

This research has several limitations. First, this research mainly focuses on hypotheses derived from transaction cost theory, applied at the firm-level. Future research needs to investigate 3PP services based on other theoretical frameworks, for example, the resources-based view and social capital theory. Such research might also highlight additional avenues for 3PLs to promote 3PP services to customers by enabling them to focus on their core competencies. Furthermore, the fact that the survey focused on the overall aggregation of transactions at the firm-level does limit the predictive power of TCE and further research on this theme should drop the unit of analysis to the transaction. Second, this research measures the four factors (viz., asset specificity, uncertainty, transaction frequency, and transaction size) related to 3PP services. Future studies may explore additional factors that may influence 3PP services for 3PL providers and users, for example, trust, performance of 3PLs, global economics, the cycle period of customer purchasing, and seasonal factors. Further research is also required to understand the results from H1 (the impact of asset specificity on 3PP services); the non-significant findings reported in our study are in contrast to expectations and may require further qualitative investigation to understand how 3PLs manage and address asset specificity and how they assess the risks associated with non-redeployable assets. Third, this research focuses only on the perspective of the 3PL providers and neglects behavior of the clients. Future research may examine 3PP services from the perspectives of suppliers and customers, perhaps using a paired sample. Such research should focus on the differences in the providers' perspectives reported here and the customer perspectives (reported in Shi et al., 2016b), specifically in relation to the factors of size and frequency and the impact on 3PP service developments. Fourth, 
this research emphasizes 3PP as a value-added service. In fact, 3PL providers have other options for value-added services to increase profits and obtain sustainable business growth. Thus, future studies may investigate and identify other value-added services that may be developed by 3PLs, for example, reverse logistics network planning and customized logistics solutions.

\section{REFERENCES}

Adobor, H., \& McMullen, R. S. (2014). Strategic purchasing and supplier partnerships — The role of a third party organization. Journal of Purchasing and Supply Management, 20(4), 263-272. http://doi.org/10.1016/j.pursup.2014.05.003

Andersson, D., \& Norrman, A. (2002). Procurement of logistics services - A minutes work or a multi-year project? European Journal of Purchasing and Supply Management, 8(1), 3-14.

Armstrong, J. S., \& Overton, T. S. (1977). Estimating nonresponse bias in mail surveys. Journal of Marketing Research (JMR), 14(3), 396-402.

Atkinson, W. (2006, March 16). Outsourcing lands in procurement. Purchasing, 135(4), 46.

Bartlett, M. S. (1950). Tests of significance in factor analysis. British Journal of Statistical Psychology, 3(2), 77-85. http://doi.org/10.1111/j.2044-8317.1950.tb00285.x

Bhatnagar, R., \& Teo, C. (2009). Role of logistics in enhancing competitive advantage: A value chain framework for global supply chains. International Journal of Physical Distribution \& Logistics Management, 39(3), 202-226. http://doi.org/10.1108/09600030910951700

Bienstock, C. C., \& Mentzer, J. T. (1999). An experimental investigation of the outsourcing decision for motor carrier transportation. Transportation Journal (American Society of Transportation \& Logistics Inc), 39(1), 42-59.

Chapman, T. L., Gupta, A., \& Mango, P. D. (1998). Group purchasing is not a panacea for US hospitals. The McKinsey Quarterly, (1), 160+.

Coase, R. H. (1937). The nature of the firm. Economica, 4(16), 386-405. http://doi.org/10.2307/2626876

Cook, T. D., \& Campbell, D. T. (1979). Quasi-experimentation: Design \& analysis issues for field settings. Boston: Houghton Mifflin. 
Cousins, P. D., Handfield, R. B., Lawson, B., \& Petersen, K. J. (2006). Creating supply chain relational capital: The impact of formal and informal socialization processes. Journal of Operations Management, 24(6), 851-863. http://doi.org/10.1016/j.jom.2005.08.007

Cruijssen, F., Dullaert, W., \& Fleuren, H. (2007). Horizontal cooperation in transport and logistics: A literature review. Transportation Journal, 46(3), 22-39.

Devaraj, S., Vaidyanathan, G., \& Mishra, A. N. (2012). Effect of purchase volume flexibility and purchase mix flexibility on e-procurement performance: An analysis of two perspectives. Journal of Operations Management, 30(7-8), 509-520. http://doi.org/10.1016/j.jom.2012.08.001

Ellingsen, T., \& Johannesson, M. (2004). Is there a hold-up problem? The Scandinavian Journal of Economics, 106(3), 475-494.

Ellram, L. M., \& Billington, C. (2001). Purchasing leverage considerations in the outsourcing decision. European Journal of Purchasing \& Supply Management, 7(1), 15-27. http://doi.org/10.1016/S0969-7012(00)00004-6

Ellram, L. M., Tate, W. L., \& Billington, C. (2007). Services supply management: The next frontier for improved organizational performance. California Management Review, 49(4), 44-66.

Ellram, L. M., Tate, W. L., \& Billington, C. (2008). Offshore outsourcing of professional services: A transaction cost economics perspective. Journal of Operations Management, 26(2), 148-163. http://doi.org/10.1016/j.jom.2007.02.008

Emery, G. W., \& Marques, M. A. (2011). The effect of transaction costs, payment terms and power on the level of raw materials inventories. Journal of Operations Management, 29(3), 236249. http://doi.org/10.1016/j.jom.2010.11.003

Emiliani, M. L. (2000). Business-to-business online auctions: Key issues for purchasing process improvement. Supply Chain Management: An international Journal, 5(4), 176-186.

Eßig, M. (1999). Cooperative sourcing as a new strategic supply concept: Theoretical framework and empirical findings. In Perspectives on Purchasing and Supply for the Millenium (pp. 245256). Belfast/Dublin: IPSERA.

Fernandez, I., \& Kekale, T. (2007). Strategic procurement outsourcing: A paradox in current theory. International Journal of Procurement Management, 1(1-2), 166-179. http://doi.org/10.1504/IJPM.2007.015360

Ferrin, B. G., \& Plank, R. E. (2006). Total cost of ownership models: An exploratory study. Journal of Supply Chain Management, 38(2), 18-29. 
Fornell, C., \& Larcker, D. F. (1981). Evaluating structural equation models with unobservable variables and measurement error. Journal of Marketing Research, 18(1), 39-50. http://doi.org/10.2307/3151312

Gattorna, J., Day, A., \& Hargreaves, J. (1991). Effective logistics management. Logistics Information Management, 4(2), 2-86.

Gibbons, R. (2010). Transaction-cost economics: Past, present, and future? Scandinavian Journal of Economics, 112(2), 263-288. http://doi.org/10.1111/j.1467-9442.2010.01609.x

Goldsby, T. J., \& Eckert, J. A. (2003). Electronic transportation marketplaces: A transaction cost perspective. Industrial Marketing Management, 32(3), 187-198. http://doi.org/10.1016/S0019-8501(02)00262-6

Gotzamani, K., Longinidis, P., \& Vouzas, F. (2010). The logistics services outsourcing dilemma: Quality management and financial performance perspectives. Supply Chain Management: An International Journal, 15(6), 438-453. http://doi.org/10.1108/13598541011080428

Grover, V., \& Malhotra, M. K. (2003). Transaction cost framework in operations and supply chain management research: Theory and measurement. Journal of Operations Management, 21(4), 457-473. http://doi.org/10.1016/S0272-6963(03)00040-8

Hair, J. F., Black, W. C., Babin, B. J., \& Anderson, R. E. (2014). Multivariate data analysis (7th ed.). Harlow: Pearson Education.

Handley, S. M., \& Benton Jr., W. C. (2013). The influence of task- and location-specific complexity on the control and coordination costs in global outsourcing relationships. Journal of Operations Management, 31(3), 109-128. http://doi.org/10.1016/j.jom.2012.12.003

Hanna, J. B., \& Maltz, A. (1998). LTL expansion into warehousing: A transaction cost analysis. Transportation Journal, 38(2), 5-17.

Hofer, A. R., Knemeyer, A. M., \& Dresner, M. E. (2009). Antecedents and dimensions of customer partnering behaviour in logistics outsourcing relationships. Journal of Business Logistics, 30(2), 141-159. http://doi.org/10.1002/j.2158-1592.2009.tb00116.x

Holcomb, T. R., \& Hitt, M. A. (2007). Toward a model of strategic outsourcing. Journal of Operations Management, 25(2), 464-481. http://doi.org/10.1016/j.jom.2006.05.003

Holmström, B., \& Roberts, J. (1998). The boundaries of the firm revisited. Journal of Economic Perspectives, 12(4), 73-94.

Hong, J., \& Liu, B. (2007). Logistics development in China: A provider perspective. Transportation Journal, 46(2), 55-65. 
Hudson, R. L., \& McArthur, A. W. (1994). Contracting strategies in entrepreneurial and established firms. Entrepreneurship: Theory \& Practice, 18(3), 43-59.

Huo, B., Ye, Y., \& Zhao, X. (2015). The impacts of trust and contracts on opportunism in the 3PL industry: The moderating role of demand uncertainty. International Journal of Production Economics, 170, Part A, 160-170. http://doi.org/10.1016/j.ijpe.2015.09.018

Jiang, B., Frazier, G. V., \& Heiser, D. (2007). China-related POM research: A literature review and suggestions for future research. International Journal of Operations \& Production Management, 27(7), 662-684. http://doi.org/10.1108/01443570710756947

Kaiser, H. F. (1970). A second generation little jiffy. Psychometrika, 35(4), 401-415. http://doi.org/10.1007/BF02291817

Kakabadse, A., \& Kakabadse, N. (2002). Trends in outsourcing: Contrasting USA and Europe. European Management Journal, 20(2), 189-198. http://doi.org/10.1016/S02632373(02)00029-4

Klein, B., Crawford, R. G., \& Alchian, A. A. (1978). Vertical integration, appropriable rents, and the competitive contracting process. The Journal of Law \& Economics, 21(2), 297-326.

Knemeyer, A. M., \& Murphy, P. R. (2006). Evaluating the performance of third-party logistics arrangements: A relationship marketing perspective. Journal of Supply Chain Management, 40(4), 35-51.

Langley, J. (2016). 2016 Third-party logistics study: The state of logistics outsourcing. Atlanta, GA: Capgemini Consulting.

Lieb, R. C., Millen, R. A., \& Van Wassenhove, L. N. (1993). Third-party logistics: A comparison of experienced American and European manufacturers. International Journal of Physical Distribution \& Logistics Management, 23(6), 35.

Light, E. (2001). 3PL: Where it's at, where it's going and why. NZ Business, 15(2), 43.

Lonsdale, C. (2001). Locked-ln to supplier dominance: On the dangers of asset specificity for the outsourcing decision. Journal of Supply Chain Management, 37(1), 22-27. http://doi.org/10.1111/j.1745-493X.2001.tb00096.x

Maltz, A. (1993). Private fleet use: A transaction cost model. Transportation Journal, 32(3), 46-53.

Maltz, A. (1994). Outsourcing the warehousing function: Economic and strategic considerations. Logistics and Transportation Review, 30(3), 245-265.

Maltz, A., \& Ellram, L. M. (1999). Outsourcing supply management. Journal of Supply Chain Management, 35(1), 4-17. http://doi.org/10.1111/j.1745-493X.1999.tb00232.x 
Manzini, R., Pareschi, A., \& Persona, A. (2006). Logistics outsourcing: An examination of thirdparty providers. International Journal of Logistics Systems and Management, 3(2), 135-157. http://doi.org/10.1504/IJLSM.2007.011819

Masten, S. E. (1984). The organization of production: Evidence from the aerospace industry. The Journal of Law \& Economics, 27(2), 403-417.

Masten, S. E., Meehan, J. W., \& Snyder, E. A. (1991). The costs of organization. Journal of Law, Economics, \& Organization, 7(1), 1-25.

McIvor, R. (2009). How the transaction cost and resource-based theories of the firm inform outsourcing evaluation. Journal of Operations Management, 27(1), 45-63. http://doi.org/10.1016/j.jom.2008.03.004

Millen, R., Sohal, A., Dapiran, P., Lieb, R., \& Wassenhove, L. N. V. (1997). Benchmarking Australian firms' usage of contract logistics services: A comparison with American and Western European practice. Benchmarking for Quality Management \& Technology, 4(1), 3446. http://doi.org/10.1108/14635779710163037

Ministry of Economic Development. (2011). SMEs in New Zealand: Structure and dynamics 2011. Wellington, New Zealand.

Minonne, C., \& Turner, G. (2012). Business process management — Are you ready for the future? Knowledge and Process Management, 19(3), 111-120. http://doi.org/10.1002/kpm.1388

Narasimhan, R., \& Jayaram, J. (1998). An empirical investigation of the antecedents and consequences of manufacturing goal achievement in North American, European and Pan Pacific firms. Journal of Operations Management, 16(2-3), 159-176. http://doi.org/10.1016/S0272-6963(97)00036-3

Narayanan, S., Narasimhan, R., \& Schoenherr, T. (2015). Assessing the contingent effects of collaboration on agility performance in buyer-supplier relationships. Journal of Operations Management, 33-34, 140-154. http://doi.org/10.1016/j.jom.2014.11.004

Nguyen, H.-O., \& Tongzon, J. (2010). Causal nexus between the transport and logistics sector and trade: The case of Australia. Transport Policy, 17(3), 135-146. http://doi.org/10.1016/j.tranpol.2009.12.005

Nollet, J., \& Beaulieu, M. (2005). Should an organisation join a purchasing group? Supply Chain Management: An International Journal, 10(1), 11-17. http://doi.org/10.1108/13598540510578333

Nunnally, J. C. (1978). Psychometric Theory (2nd ed.). New York, NY: McGraw-Hill. 
Nyaga, G. N., Whipple, J. M., \& Lynch, D. F. (2010). Examining supply chain relationships: Do buyer and supplier perspectives on collaborative relationships differ? Journal of Operations Management, 28(2), 101-114. http://doi.org/10.1016/j.jom.2009.07.005

NZBusiness. (2009). Import Fundamentals. Retrieved May 3, 2016, from http://nzbusiness.co.nz/articles/import-fundamentals

Palugod, N., \& Palugod, P. A. (2011). Global trends in offshoring and outsourcing. International Journal of Business and Social Science, 2(16), 13-19.

Panayides, P. M., \& So, M. (2005). Logistics service provider-client relationships. Transportation Research Part E: Logistics and Transportation Review, 41(3), 179-200. http://doi.org/10.1016/j.tre.2004.05.001

Parry, G., James-Moore, M., \& Graves, A. (2006). Outsourcing engineering commodity procurement. Supply Chain Management: An International Journal, 11(5), 436-443. http://doi.org/10.1108/13598540610682453

Presutti, J. W. D. (2003). Supply management and e-procurement: Creating value added in the supply chain. Industrial Marketing Management, 32(3), 219-226.

Podsakoff, P. M., \& Organ, D. W. (1986). Self-reports in organizational research: Problems and prospects. Journal of $\quad$ Management, 12(4), 544. http://doi.org/10.1177/014920638601200408

Power, D., Sharafali, M., \& Bhakoo, V. (2007). Adding value through outsourcing: Contribution of 3PL services to customer performance. Management Research News, 30(3), 228-235. http://doi.org/10.1108/01409170710733296

Rabinovich, E., Knemeyer, A. M., \& Mayer, C. M. (2007). Why do Internet commerce firms incorporate logistics service providers in their distribution channels? The role of transaction costs and network strength. Journal of Operations Management, 25(3), 661-681. http://doi.org/10.1016/j.jom.2006.05.012

Rahman, S.-U. (2008). Quality management in logistics services: A comparison of practices between manufacturing companies and logistics firms in Australia. Total Quality Management \& Business Excellence, 19(5), 535-550. http://doi.org/10.1080/14783360802018202

Ramsay, J. (1994). Purchasing power. European Journal of Purchasing \& Supply Management, 1(3), 125-138. http://doi.org/10.1016/0969-7012(94)90002-7

Reeves, K. A., Caliskan, F., \& Ozcan, O. (2010). Outsourcing distribution and logistics services within the automotive supplier industry. Transportation Research Part E: Logistics and Transportation Review, 46(3), 459-468. http://doi.org/10.1016/j.tre.2009.10.001 
Rozemeijer, F. (2000). How to manage corporate purchasing synergy in a decentralised company? Towards design rules for managing and organising purchasing synergy in decentralised companies. European Journal of Purchasing \& Supply Management, 6(1), 5-12. http://doi.org/10.1016/S0969-7012(99)00034-9

Rushton, A., Croucher, P., \& Baker, P. (2006). The handbook of logistics and distribution management (3rd ed.). London, UK: Kogan Page.

Sahay, B. S., \& Mohan, R. (2006). 3PL practices: An Indian perspective. International Journal of Physical Distribution \& Logistics Management, 36(9), 666-689. http://doi.org/10.1108/09600030610710845

Sankaran, J. (2000). Freight logistics in the New Zealand context. International Journal of Physical Distribution \& Logistics Management, 30(2), 145-164. http://doi.org/10.1108/09600030010318856

Sankaran, J., Mun, D., \& Charman, Z. (2002). Effective logistics outsourcing in New Zealand: An inductive empirical investigation. International Journal of Physical Distribution \& Logistics Management, 32(8), 682-702. http://doi.org/10.1108/09600030210444926

Sankaran, J. K., \& Wood, L. (2007). The relative impact of consignee behaviour and road traffic congestion on distribution costs. Transportation Research Part B: Methodological, 41(9), 1033-1049.

Schotanus, F., \& Telgen, J. (2007). Developing a typology of organisational forms of cooperative purchasing. Journal of Purchasing and Supply Management, 13(1), 53-68. http://doi.org/10.1016/j.pursup.2007.03.002

Selviaridis, K., \& Spring, M. (2010). The dynamics of business service exchanges: Insights from logistics outsourcing. Journal of Purchasing and Supply Management, 16(3), 171-184. http://doi.org/10.1016/j.pursup.2009.12.007

Shi, Y., \& Arthanari, T. S. (2011). Outsourcing purchasing services by third party logistics providers: A conceptual model. International Journal of Logistics Systems and Management, 10(4), 398-419. http://doi.org/10.1504/IJLSM.2011.043102

Shi, Y., Zhang, A., Arthanari, T., Liu, Y., \& Cheng, T. C. E. (2016a). Third-party purchase: An empirical study of third-party logistics providers in China. International Journal of Production Economics, 171, Part 2, 189-200. http://doi.org/10.1016/j.ijpe.2015.08.028

Shi, Y., Arthanari, T., \& Wood, L. C. (2016b). An empirical study of third-party purchase: New Zealand users' perspective. Applied Economics, 48(56), 5448-5461. https://doi.org/10.1080/00036846.2016.1178847 
Sink, H. L., \& Langley, C. J. (1997). A managerial framework for the acquisition of third-party logistics services. Journal of Business Logistics, 18(2), 163-189.

Skjoett-Larsen, T. (2000). Third party logistics - from an interorganizational point of view. International Journal of Physical Distribution \& Logistics Management, 30(2), 112-127. http://doi.org/10.1108/09600030010318838

Sohail, M. S., Bhatnagar, R., \& Sohal, A. S. (2006). A comparative study on the use of third party logistics services by Singaporean and Malaysian firms. International Journal of Physical $\begin{array}{llll}\text { Distribution } \quad \& \quad \text { Logistics } \quad \text { Management, } & \text { 36(9), }\end{array}$ http://doi.org/10.1108/09600030610710854

Sohal, A. S., \& Rahman, S. (2013). Use of third party logistics services: An Asia-Pacific perspective. In J. H. Bookbinder (Ed.), Handbook of Global Logistics (pp. 45-67). Springer New York. Retrieved from http://link.springer.com/chapter/10.1007/978-1-4419-6132-7_3

Spina, G., Caniato, F., Luzzini, D., \& Ronchi, S. (2013). Past, present and future trends of purchasing and supply management: An extensive literature review. Industrial Marketing Management, 42(8), 1202-1212. http://doi.org/10.1016/j.indmarman.2013.04.001

Stratman, J. K. (2008). Facilitating offshoring with enterprise technologies: Reducing operational friction in the governance and production of services. Journal of Operations Management, 26(2), 275-287. http://doi.org/10.1016/j.jom.2007.02.006

Stump, R. L. (1995). Antecedents of purchasing concentration: A transaction cost explanation. Journal of Business Research, 34(2), 145-157. http://doi.org/10.1016/0148-2963(94)00114-T

Tella, E., \& Virolainen, V.-M. (2005). Motives behind purchasing consortia. International Journal of Production Economics, 93-94, 161-168. http://doi.org/10.1016/j.ijpe.2004.06.014

Tyndall, G., Gopal, C., Partsch, W., \& Kamauff, J. (1998). Ten strategies to enhance supplier management. National Productivity Review, 17(3), 31-44. http://doi.org/10.1002/npr.4040170307

Van Weele, A. J. (2010). Purchasing and Supply Chain Management: Analysis, strategy, planning and practice $\left(5^{\text {th }}\right.$ ed.). Hampshire, UK: Cengage Learning.

Verwaal, E., \& Donkers, B. (2003). Customs-related transaction costs, firm size and international trade intensity. Small Business Economics, 21(3), 257-271. http://doi.org/10.1023/A:1025702520091

Walker, G., \& Weber, D. (1987). Supplier competition, uncertainty, and make-or-buy decisions. Academy of Management Journal, 30(3), 589-596. http://doi.org/10.2307/256017 
Williamson, O. E. (1975). Markets and hierarchies, analysis and antitrust implications: A study in the economics of internal organization. New York: Free Press.

Williamson, O. E. (1981). The modern corporation: Origins, evolution, attributes. Journal of Economic Literature, 19(4), 1537-1568.

Williamson, O. E. (1985). The economic institutions of capitalism: Firms, markets, relational contracting. New York: Free Press.

Williamson, O. E. (2008). Outsourcing: Transaction cost economics and supply chain management. Journal of Supply Chain Management, 44(2), 5-16. http://doi.org/10.1111/j.1745493X.2008.00051.X

Wilson, M. M. J., \& Roy, R. N. (2009). Enabling lean procurement: A consolidation model for small- and medium-sized enterprises. Journal of Manufacturing Technology Management, 20(6), 817-833. http://doi.org/10.1108/17410380910975096

Yang, Q., \& Zhao, X. (2016). Are logistics outsourcing partners more integrated in a more volatile environment? International Journal of Production Economics, 171, Part 2, 211-220. http://doi.org/10.1016/j.ijpe.2015.09.036

Zheng, J., Knight, L., Harland, C., Humby, S., \& James, K. (2007). An analysis of research into the future of purchasing and supply management. Journal of Purchasing and Supply Management, 13(1), 69-83. http://doi.org/10.1016/j.pursup.2007.03.004 


\section{Appendix: SEM measures included in the questionnaire}

\section{Asset specificity measures:}

The purchasing of each order requires close coordination with your organization's customers.

$\square 1$ (Strongly Disagree) $\square 2$ (Disagree) $\square 3$ (Neutral) $\square 4$ (Agree)

$\square 5$ (Strongly Agree)

You have made significant investments in purchasing function resources dedicated to your customers.

$\square$ 1 (Strongly Disagree) $\square 2$ (Disagree) $\square 3$ (Neutral) $\square$ 4 (Agree)

$\square 5$ (Strongly Agree)

Your organization could leverage the purchasing function to build relationships with customers.

$\square$ ( (Strongly Disagree) $\square 2$ (Disagree) $\square 3$ (Neutral) $\square$ 4 (Agree)

$\square 5$ (Strongly Agree)

On average, your customer's routines and working procedures are difficult processes to be transferred to your organization.

$\square$ ( (Strongly Disagree) $\square 2$ (Disagree) $\square 3$ (Neutral) $\square$ 4 (Agree)

$\square 5$ (Strongly Agree)

\section{Uncertainty measures:}

Demand forecasting for purchasing outsourced to your organization is:

$\square 1$ (Very Difficult) $\square 2$ (Difficult) $\square 3$ (Neutral) $\square$ 4 (Easy) $\square 5$ (Very Easy)

Your organization is confident that outsourcing purchasing services would return value to your organization.

$\square$ ( (Strongly Disagree) $\square 2$ (Disagree) $\square 3$ (Neutral) $\square$ 4 (Agree)

$\square 5$ (Strongly Agree)

Evaluating the current purchasing performance offered by your organization is:

$\square 1$ (Very Difficult) $\square 2$ (Difficult) $\square$ 3 (Neutral) $\square$ 4 (Easy) $\square 5$ (Very Easy)

You expect to offer purchasing services for a relatively long period.

$\square 1$ (Strongly Disagree) $\square 2$ (Disagree) $\square 3$ (Neutral) $\square$ 4 (Agree)

$\square 5$ (Strongly Agree)

\section{Order frequency measures:}

Increased frequency of purchasing orders could reduce the fixed cost per transaction.

$\square 1$ (Strongly Disagree) $\square 2$ (Disagree) $\square 3$ (Neutral) $\square$ 4 (Agree)

$\square 5$ (Strongly Agree) 
As transaction frequency increases, the costs for your customers to monitor purchasing activities will increase.
$\square 1$ (Strongly Disagree) $\square 2$ (Disagree) $\square 3$ (Neutral) $\square$ 4 (Agree)
$\square 5$ (Strongly Agree)

As transaction frequency increases, your organization will increase the negotiation power to reduce purchasing costs for your customers.
$\square$ 1 (Strongly Disagree) $\square 2$ (Disagree) $\square$ 3 (Neutral) $\square$ 4 (Agree)
$\square 5$ (Strongly Agree)

\section{Transaction size measures:}

Combining purchasing orders together may reduce the purchasing costs.
$\square$ 1 (Strongly Disagree) $\square 2$ (Disagree) $\square 3$ (Neutral) $\square$ 4 (Agree)
$\square 5$ (Strongly Agree)

You could have more power in the negotiation with suppliers when using consolidation in real procurement practice.
$\square$ 1 (Strongly Disagree) $\square 2$ (Disagree) $\square 3$ (Neutral) $\square 4$ (Agree)
$\square 5$ (Strongly Agree)

You receive more benefits if your purchase orders are large.
$\square$ 1 (Strongly Disagree) $\square$ 2 (Disagree) $\square$ 3 (Neutral) $\square$ 4 (Agree)
$\square 5$ (Strongly Agree)

\section{3PP service measures:}

Which of the following purchasing activities can be offered by your organization?

\begin{tabular}{|c|l|l|l|l|l|l|}
\hline S/N & Purchasing activity & $\begin{array}{r}\text { Very } \\
\text { Unlikely }\end{array}$ & Unlikely & Neutral & Likely & Likely \\
\hline A & Category management & & & & & \\
\hline B & Supplier market research & & & & & \\
\hline C & Supplier qualification and selection & & & & & \\
\hline D & Request for proposal management & & & & & \\
\hline E & Bid preparation and management & & & & & \\
\hline F & Cost analysis & & & & & \\
\hline G & Supplier relationship management & & & & & \\
\hline
\end{tabular}




\section{Value-to-client measures:}

You would intend to help your customers minimize purchasing risks if you were providing or willing to offer this service.

$\square$ ( (Strongly Disagree) $\square$ (Disagree) $\square$ (Neutral) $\square$ (Agree)

$\square 5$ (Strongly Agree)

You would intend to maintain a long-term relationship with your customers.

$\square$ 1 (Strongly Disagree) $\square$ (Disagree) $\square$ (Neutral) $\square$ (Agree)

$\square 5$ (Strongly Agree)

You would intend to help your customers focus on their own core business.

$\square$ 1 (Strongly Disagree) $\square$ (Disagree) $\square$ (Neutral) $\square$ (Agree)

$\square 5$ (Strongly Agree) 
This is the post-print (i.e., it is the authors' final draft, post-refereeing, and is therefore the authors' accepted manuscript) of the article:

Shi, Y., Arthanari, T. S., \& Wood, L. C. (2017). Developing third-party purchase (3PP) services: New Zealand third-party logistics providers' perspectives. Supply Chain Management: An International 